\title{
A STUDY ON CODE SWITCHING USED BY MALINAU STUDENTS IN LAMONGAN
}

\author{
Senja Sri Wanti Ningsih, Dian Luthfiyati \\ senjasriwantiningsih0695@gamail.com, dian.luthfiyati@gmail.com \\ Madrasah Ibtidaiyah Kabupaten Malinau, Program Studi Pendidikan Bahasa Inggris Universitas Islam \\ Lamongan
}

\begin{abstract}
Language is foremost a means of communication used by people to convey their ideas and feelings to others when they talk directly or indirectly. Current phenomenon is common in society the code switching used by individuals who live in a bilingual or multilingual community in which the code switching can occur. The researcher chooses one of Malinau students in Lamongan. Her name is "Siti Bakhiatus Sholikhah" Faculty of Fisheries, Lamongan Islamic University, on eighth semester. The purpose of this study is to find out the types of code switching and find out the functions of code switching used by Malinau Student in Lamongan. This study examines the types of code switching that occurred during the conversations used by Malinau Students in Lamongan. The research design of this study is using qualitative descriptive method. The collection technique of the data is from of recording and chatting in social media : like a WhatsApp and Facebook from "Lika's" talks. The data analysis techniques used found that are preparing, reading and undesrtanding, coding and classifying, interpreting and drawing te conclusion. From this data found the types and functions of code switching are analyzed by using the theory of Poplack's and Apple and Muysken. From the results of analysis, three types of code switching (tag switching, inter-sentential switching and intra-sentential switching) and four functions of code switching are (referential function of code switching, directive function of code switching, expressive function of code switching and metalinguistic function of code switching).
\end{abstract}

Keywords: Code switching, Malinau students

\section{INTRODUCTION}

Sociolinguistics is a study of the relationship between language and society. It has 3 functions, there are a language, community, and relationships of language. Language is the ability of humans to communicate with other humans using signs, such as words and movements or some instruments for interacting and communicating, in the sense of instrument how people to express, thoughts, ideas, concepts or feelings.

According to Stockwell (2002) sociolinguistics must be familiar with a code. A code is a symbol of nationalism that is used by people to speak or communicate in a particular language a dialect a register, an accent or a style on different occasions and for different purposes a code is divided into code mixing and code switching.

Code
switching or (transfer
language) an alternative to have a

conversation with two different languages, where the current code switching to be a widespread phenomenon in a foreign language teaching. However, code switching there are speakers, listeners, syllabic changes, or formal and informal situation to change of the topic.

Malinau which is part of the new province of the North Kalimantan, is originally of Tidungnese and Dayaknese community. Mentioning the named of Malinau comes from the Dutch people who live in the area and they asked one of the most people in the dialogue with a group of Abai tribe who made of sago from sugar palm. Then the Dutch asked: "What is the name of this river?" That is the river in their village. The people who got the question did not understand. They only suspect the intent of the Dutch question, they do or what they do. Then one of them replied: "Mal Inau dako", 
which means is processing or cooking palm sago / palm sugar. Mal means making, while Inau means enau tree / aren. The Dutch asked him to record it. So the name of Malinau was born by the accident.

Malinau has a type of language, the words are "bah" or "kah" is there an Indonesian accent mixed with the dialogue people in Malinau. Now, in Indonesian language, especially in Malinau, Many factors which influenced the people mix the code, such as their background as like education, culture, social. People speak based on where they came from and their environment. When people are in conversation they use the language that they have, generally people often use more than one language.

The phenomenon using of code switching in the individual who lived in bilingual and multilingual community. It is very common that people develop some knowledge and ability in a second language and so become bilingual. The simplest definition of a bilingual is a person who has some functional ability in a second language.

Malinau Students in Lamongan can be categorized just a few. The researcher chooses on one of figures who often expose the use of code switching in her utterance namely "Siti Bakhiatus Sholikhah" but in this case the researcher wants to discuss how to adapt of Malinau students in Lamongan with the dialogue and accent when they spend of some speech with other people. Example, using the Javanese language, Indonesian or Malinau language used by daily of her spoken.

In this study, the reason why the researcher chooses the title, because the researcher want to know about Malinau language and the type of the dialect in Malinau. So, the readers know how the culture and linguistic differences that spreads in Indonesia through students who immigrate from one place to another.

\section{Sociolinguistics}

According to Holmes (1972:2), ssociolinguistics is the study of the relationship between language and society. Social humans beings who cannot live alone but always interact with each other. For this purpose, human life uses a language as a communication in the community. This formation can prove that the language in the world that has unique characteristics by socially relevant factors, such as class, profession, age or gender. People use all these connections when they try to analyze language from a social perspective.

According to Trudgill (1992:13), bilingualism is the ability of an individual to speak two or more languages. Sociolinguiststics agree that bilingualism is so widespread in the world that there are probably more people in the world who are bilingual, at least in the second sense of the term, and then there are monolinguals. Many sociolinguistics use the term "bilingualism" to refer to individuals, even if they are trilingual and reserve the term multilingualism for nation or societies, even if only two languages are involved. Other experts give a definition of bilingualism as follows :

1. He can produce meaningful sentences in L2 (Haugen, 1969).

2. He can engage in communication in more than one language (Fishman 1968).

3. He speaks only one language, but uses different language varieties, register and style of that language (Holliday and Strevens, 1964).

According to Hoffman (2008), multilingualism describes the ability to speak more than two languages and comes about when speakers of different languages are brought together within the same political entity. Although there is barely a difference towards the concept of bilingualism, multilingualism remains a topic worth mentioning since many parts of the world. This phenomenon has 
become an indisputable fact of life. The fact that speakers select different languages or varieties for use in different situations shows that not all languages / varieties are equal or regarded as equally appropriate or adequate for use in all speech events.

Bilingualism and multilingualism have both the factor existences and important places in the psychological, political, and social debates that define social and ethnic groups, communities, and regions. Very widespread phenomena, they arise for a number of well understood reasons, in the main, however, they are also quite unremarkable phenomena, fueled by necessity up to, but rarely beyond, appropriately useful levels of competence.

\section{Definition of Code}

According to Wardhaugh (1986: 3), a code is a system of communication that people employ when two or more of them communicate with each other in speech. He adds that in most cases code will be something we may want to call a language. In many parts of the world, it is just a normal requirement in daily living that people speak several languages, perhaps one or more at home, another in the village, still another for purposes of trade, and yet another for contact with the outside world of wider social or political organization.

\section{Code Switching}

Code switching is decided to switch from one code to another or to mix codes even within sometimes very short utterances and thereby create a new code (Wardhaugh,1997:103). From the definition above, it is that learned about code switching utterance in one language to mix with another language found in the bilingual or multilingual speech. People, then, are usually required to select a particular code whenever they choose to speak.

\section{Code Mixing}

According to Kachru (1978:28), code mixing uses this concept to refer to the use of one or more languages for consistent transfer of linguistic units from one language into another and by such a language mixture developing a new restricted or not restricted code of linguistic interaction. From the definition above, code mixing is a language unit from one language to another to extend the style of the language or the variety of languages. Included is the use of words, clauses, idioms, greetings, etc.

\section{Differences of Code Switching and Code Mixing}

The differences between code switching and code mixing there are code switching is a code overrides occur to suit the roles in the topics covered and the specific goals. While, code mixing can occur without any discussion topic in a language situation requiring of some mixed of language. But, it can be the factual factors, habits or the things.

\section{Types of Code Switching}

This section presents the general classification of code switching from some linguist as a follow, Code switching can be classified into three types: tag-switching, inter-sentential switching and intrasentential switching by Poplack (1980) as citied in Romaine (1995:122-123). This division is based on the scope of switching or the nature of the juncture in which the language alternation takes place:

\section{Tag Code Switching}

Tag code switching is a tag from one language into an utterance which is entirely in the other language. Tag code switching is a subject to minimal syntactic, therefore tags may be easily inserted at a number of points in a monolingual utterance without violating syntactic rules. 
2. Inter-sentential Code Switching

Inter-Setential Code Switching is a requires speaker to have greater fluency in both languages. Say of merely to have an ability to tag-switch, because the major portion of the utterance has to conform to the rules of both languages.

\section{Intra-Sentential Code Switching}

Intra-Setential Code Switching of language is that alternation occurs within a sentence or a clause boundary. Sometimes it includes mixing within word boundaries, because this type of code switching involves the greatest syntactic risk.

\section{The Function Of Code Switching}

The function of code switching based on the theories proposed by Gumperz and associates, Poplack, and, Scotton (in Apple and Muysken, 1987:118-120) summarize four of six the function of code switching, will be presented one by one according to each function of code switching :

1. Referential Function of Code Switching

The referential function of code switching refers to this function occurs when there is a lack of knowledge of one language on certain subjects. In this certain subject, perhaps more appropriately discussed in one language and the introduction of such a subject it can lead to a switch.

2. Directive Function of Code Switching

The Directive function of code switching can involve the hearer directly. A very simple example was also given by Apple and Muysken. Many parents try to speak a foreign language when they do not want their children to understand what is being said.

3. Expressive Function of Code Switching

The expressive function It shows that the speakers emphasizes a mixed identify through the use of two languages in the same discourse. In this study, for example the conversation full of code switching is a mode of speech by itself, and individual switches no longer have a discourse function. This function may not be present in all code switching communities.

\section{Metalinguistics Function of Code Switching}

The metalinguistics function of code switching comes into play when it is used to comment directly on the languages involved. An example is when speakers switch between different codes to impress the other participants with a show of linguistic skills (Scotton, 1979; in Appel and Muysken, 1987:120).

From the review of literature above, we can see the phenomenon of code switching is closely related to language and society, bilingualism and multilingualism, code, type of code switching and the function of code switching. Therefore, this research shows that the references of language and society can also explain the phenomenon of code switching used by Malinau students in Lamongan.

Moreover, after discussing some theories which are related to code switching the researcher used code switching proposed by Poplack (1980) as citied in Romaine (1995:122-123) and Gumperz and associates, Poplack, and, Scotton (in Apple and Muysken, 1987:118-120) based on the type of code switching or the nature of the juncture in which the language alternation take place, there are tag code switching, intersentential code switching, intra-sentential code switching and the function are referential, directive, expressive and metalinguistics function of code switching.

\section{Malinau Students of Code Switching Phenomena}

Malinau Students are the Students from the Malinau, North Kalimantan They 
have to learn about some purposed to studying in Lamongan. Therefore, why the researcher collects the data about something different language and culture in Lamongan behind the students from Malinau.

The purpose for learning of code switching is how they can find out to something mixed of the languages between Malinau language and Javanese or Indonesian language owned by Malinau Students in Lamongan.

"Siti Bakhiatus Sholikhah" was born in Balikpapan, December 24, 1996. She's from Lamongan but She's already staying in Kalimantan. His family from the real Javanese. His father from Turi Lamongan and his mother from Plosowahyu Lamongan. She is also to adapt and learning for the Language in Lamongan such as, Javanese or Indonesian language than his meeting with his friends to understand what they're told. This research focused on the types and function of Code Switching used by Malinau Students in Lamongan.

\section{METHOD}

This research is classified as descriptive qualitative method. The reseacher took "SITI BAKHIATUS SHOLIKHAH" or "Lika's" she is Malinau student of eighth semester in Lamongan Islamic University as an object, while the subject of this research is about the code switching used by Malinau student. In this sentence can found in Malinau students on their naturalness spoken in Lamongan. However, the data can be sourced from social media (WhatsApp and Facebook) or recording by mobile phone when she was talking with her friends in Lamongan to classify the type of code switching and the function of code switching.

The researcher intended to describe the data obtained, as they were found in the field. After collecting the data, the researcher took the next step that is analyzing the data. The method of analyzing data that are used in this research related to Creswell's theories by doing following steps (Creswell, 2009:183):

1. Preparing the Data for Analysis

This involved transcribing chatting and recording of conversation in the sentences of code switching used by Malinau students in Lamongan.

2. Reading and Understanding all the Data

This step was to obtain a general sense of the information and to reflect on its overall meaning.

3. Classifying all the Data.

The researcher started to classify the data one by one when all the switched expression in Malinau students used of code switching sentences in Lamongan. Has been marked by the analysis framework as presented:

- Appendix 1 : type of code switching (tag-code switching).

- Appendix 2 : type of code switching (inter-sentential code switching).

- Appendix 3 : type of code switching (intra-sentential code switching).

This step was to answer the research problem numbers one and two. The researcher classified the data that had been 62 marked based on the three types of code switching and the function using it.

4. Making an Interpretation or Meaning of the Data.

After the classification was done, systematically the researcher describing the type types of code switching and the function of code switching Used by Malinau students in Lamongan.

5. Drawing Conclusions

The writer concluded about code switching that mostly occurs the types of code switching used by Malinau students in Lamongan and will conclude which function of code switching used by Malinau students in Lamongan. 


\section{DISCUSSION}

\section{Types of Code switching Used by Malinau Students in Lamongan}

The Analysis of The Type of

Code Switching The analysis of types of code switching based on the theory proposed by Poplack (1980) as citied in Romaine (1995:122-123). In the daily communications, sometimes Malinau students switched of the language from Malinau into Indonesian or Javanese or from English into Malinau dialect. The Code Switching which occurs among them falls into varieties of type. The types of Code Switching can be classified as follows:

1. Tag Code Switching

Tag code switching is called tag switching when an utterance by a tag exclamation, or a parenthetical or entirely different language. Generally, tag switching is used to emphasize something or express some kind of feeling as a sudden surprise. Tag code switching can be shown as follows as seen in data 1, 2, 3, 4, 5 and 6:

\section{Data 1}

[1] Lika : kamu sibuk kah hari ini nah? Lika : nah, ngak jadi aku kerumahmu hari ini, "mata ku kena cabai". (1) Janut : iya tii, nanti aja kamu kesini yah, cepet sembuh yah sayang ku.

In the data (1) English tag "mata ku kena cabai" is followed with Malinau sentence iya tii, nanti aja kamu kesini yah, cepat sembuh yah sayang $\mathrm{ku}$.

[2] Lika : hati - hati yah kamu baliknya. Ujie : hahaha iya nyo.

Lika : jam berapa nanti balik nyo.

Ujie : ndak tau nyo, nanti pesawat jam 12.55 dari rumah jam berapa yak?

Lika : setengah 11 nyo.

Ujie : dari rumah nyo.
Lika : rumah ke bandara jam berapa??

Ujie : ke tempat mu sekitar 15 menit kemarin.

Lika : iya jam segitulah berarti berangkat. Jam 11 check in kan??

Ujie : jam 10.55 hahaha, tapi kalo sejam sebelum jalan jam 11.55.

Lika : ya udah, terserah deh tapi jangan mepet, barang butuh masuk bagasi

kan?

Ujie : ia nyo, jam segitu aja aku jalan.

Lika : "minimal sejam sebelum take off lah. Udah check in?

Ujie : nah kurang tau, 30 menit kayaknya jam 11 lah ku check in.

Lika : nanti nyo kamu balik.

Ujie : hmmm.

Lika : jangan buru - buru.

Ujie : "malas aku balik nah," tapi ya sudah lah. Iya nyo. (2)

Lika : "ndak kangen kah kalau ndak

balik." (3)

Ujie : Kangen.

In the data (2), (3) English tag expression about ujie said that is for lazy expression "malas aku balik nah" and lika's answer "ndak kangen kah kalau balik" that is the missing expression to give for Ujie's.

[3]Lika : ke tg. Tadi malam?

Nhuel : iya bs baru pulang lagi.

Lika : "ndak ngasih tau." (4)

Nhuel : "aku pun mendadak mau perginya kasihan”. (5)

In the data (4) and (5) English tag give expression of Lika's said " $\boldsymbol{n d a k}$ ngasih tau" there is apart of dissapointed expression for lika's to his friends. And "aku pun mendadak mau perginya kasihan" his friends give the sadness expression to Lika's.

[4] Janut : tidur sama ulenya dia hehehe "tahan juga dia tidur sama kau ti" haha. 
(6) Lika : hehe, ada mamaknya nah tadi habis youtube.an sama aku tuh “modelnya jadi kek gitu.” Udah pindah rumah kah nah? Nahhhhhhh?

(7)Janut : belum kami pindah tii, mungkin ada kali 1 mingguan lebih. "kamu sampai kapan disini sayang?" Kalau ada waktu main kesini aku jemput ditambangan hehehe. (8)

In the data (6) English tag give the expression about "Tahan" that is expression about the comfortable person to other people can give the expression "Tahan" juga dia tidur sama kau ti. for his frineds with Malinau sentence For data (7) modelnya jadi "kek" gitu with Malinau sentence give the expression about the moddeling of Lika's nephew to telling his friends when his nephew making for many model. And data (8) "kamu sampai kapan disini "sayang?" give the expression about lovely friends to asking for someone.

[5] Cilla : kapan bs?

Lika : kamu hari ini sibuk kah cill?

Cilla : iya lumayan bs.. memangnya hari ini kah jalannya bs?

Lika : pengennya cill.. tapi lain kali juga gapapa. "Bosan aku bah cill ndak pernah jalan.” Kamu kerja kah?? (9)

Cilla : iyaaa, ini aku kerja. Mainlah ke sini bs ke sabanar lama

Lika : ganggu kerja mu lah aku cill kalau aku kesana. Sampai jam berapa kamu kerja cill?

Cilla : aku juga pengen jalan - jalan, lama aku ndak jalan - jalan.

In the data (9) English tag "Bosan" with Malinau sentence "aku bah cill ndak pernah jalan" give the expression about the lazy time.

[6] Lika : Tutii, ini aku bs, tutii tau kah tempat pembuatan amplang?

Tuti : ada sih yang aku, tapi ngak tau masih buat atau tidak.
Lika : dimana tutii? Aku butuh buat nyusun skripsii.

Tuti : kalau gak salah di sabanar lama. Yang kuat ya.

Lika : alamatnya? Kamu tau kah lokasinya tii? Iyaa.

Tuti : nanti tak cek kan.

Lika : “makasih ti ya, semoga allah selalu melimpahkan kebaikan buat mu." (10)

Tuti : amin. RT.9 tidak ada di sabanar. Lika : iyah lah tii, nanti kulihat di bungkus amplang.

Tuti : kayaknya selimau tuh, tapi nanti coba aku cari lagi.

Lika : "iya ti'. Makasih banget yah."

(11) Tuti : “iya sama-sama.”(12)

In the data (10), (11) and (12) English tag gives the expression about "makasih" with Indonesia sentence that is grateful expression to give the person. In tag code switching the speakers often take place in exclamination. When the speakers express her emotional she/he will feel for sadness, happiness, and disappointed expression can give the person.

2. Inter - Sentential Code Switching.

Inter-sentential code

switching occurs between a clause or sentence boundary where each clause or sentence is in one language or the other. The Inter - Sentential Code Switching can be shown as follows at seen in data $7,8,9,10,11,12,13,14$ and 15 :

\section{Data 2}

[7] Fuad : iyo ta dek?

Lika : iyo lah.

Fuad : turu karo lele lak bahagia dek.

Lika : "yo menyedihkan kak". (13)

Fuad : "jare bahagia dek." "Wes

kadong cinta karo lele ndelok lele ae bahagia". (14)

Lika : iyo gapopo, lebih apik toh nek ngelihat lele ae bahagia, hemat 
biaya iya, "ngurangi resiko kalo jalan - jalan juga iya". "Enak kan". (15)

Fuad : ya begitu lah.

In the data (13), (14) and (15) code switching occurs within in sentence, this sentence has been happened because there is switching from Javanese into Indonesian to self regional dialect or Indonesian to Javanese language.

[8] Naim : lika aku njalok nomere makmu.

Lika : "lagek mau aku telfon emak tak gabungno tapi nomere samean gak kenek ditelpon kak. Iyo tak inbox." (16)

Naim : "sing kenek di gawe video call." (17)

Lika : "gak onok, onok.e nomere mbak tapi jarang aktif." (18)

Naim : nomer biasa ae.

Lika : iyo uwes tak inbox kak.

Naim : Y.

In data (16), (17) and (18) the switching in the sentence above when the utterance starts in Javanese to English and Indonesian.

[9] Kak wahit : lika.

Lika : dalem.

Kak wahit : wes balik nang lamongan ta?

Naim : uwes kak, iki nak kampus.

Kak wahit : sabtu gak libur ta.. piye kabare ortu?

Lika : "wes gak onok kuliah kak, bimbingan, Alhamdulillah kak." (19)

Kak wahit : sekripsine wes mari durung?

Lika : durung kak.

In the data (19) the switching in the sentence starts in Javanese to Arab language " "wes gak onok kuliah kak, bimbingan, alhamdulillah kak."

[10] Lika: muduno ya, aku na bp wisan.

Kak puad : nek endi .
Lika : samean nandi?? Sesok tak tukokno maneh.

Kak puad : "gak ikhlas iki ketoro." (20)

Lika : “kok aku?? Yo samean iku seng gupuh. Lapo koq gakikhlas koq tak tukokno pil barang." (21)

Kak puad : "wes lerem iki gak tak ombeni obat." (22)

Lika : sesok ditukono jamu gak??

Kak puad : gak usa.

In the data (20), (21) and (22) the switching in the sentence can utterance starts in Javanese language into Indonesian language.

[11] Panjul : balik njul.. hati - hati.

Lika : iya njul.

Panjul : oleh - olehnya ba.

Lika : kui gambar.

Panjul : gambar tok pait.

Lika : jemput sby njul tak kek i.

Panjul : "kau ngomong juga mendadak bah." (23)

Lika : "sengojo ben gak ngekek,i oleh - oleh njul.” (24)

Panjul : kapan kau main kesini, omong tok.

Lika : arep nak kampus sayang.

In the data (23) and (24) the switching in the sentence above when the utterance starts in Malinau sentence "kau ngomong juga mendadak bah.", and then switches into Javanese sentence "sengojo ben gak ngekek,i oleh - oleh njul."

[12] Lika : “dirumah kak, mau balik bah aku kak.” (25)

Kak eko : "hemmmm, langsung balik deh, tapi kan enak ndek kene dek. Wohhh enek urusan toh.” (26)

Lika : iyaaa. Wes suih kene kak.

In the data (25) and (26) the switching in the sentence above when the utterance starts in Malinau sentence "dirumah kak, mau balik bah aku kak.", and then switches into Javanese 
sentence "hemmmm, langsung balik deh, tapi kan enak ndek kene dek. Wohhh enek urusan toh."

[13] Lika : sesok aku nebeng na kampus, na omah motore di gae kabeh min.

Haimin : jam piro? Amu mene nggowo laprop ta lik?

Lika : jam 12 pak angky na kampus, gowolah nek awakmu butuh

Haimin : "terus ketemu jam piro bekne amu dikandani, lah emang amu nggowo gak ngunu." (26)

Lika : jam 12 haiminnn. Ndelok sesok ae, nek awakmu butuh yo tak gawakno.

In the data (26) the switching in the sentence above when the utterance starts in Indonesian sentence into Javanese sentence "terus ketemu jam piro bekne amu dikandani, lah emang amu nggowo gak ngunu." (26)

[14] Karneng : pean nek endi saiki.

Lika : puskesmas ges, engko budal na kampus..

Karneng : okee. Aku wes na lamongan iki.

Lika : samean nandi ges??

Karneng : nang kost gess ngerjakno iki.

Lika : okkeh gess.

Karneng : pak angky jam 1 gess.

Lika : okkeh ges.

Karneng: "aku nang gedung utama iki gess. Nunggu BRI buka.” (27)

Lika : aku nak Tu, pak angky wes nyampe ta ges.

Karneng : gorong ono mobile ges.

Lika : tak kiro naik kereta ges

Karneng : gak sido ges jare, mbak yanti wes budal ta ges.

Lika : durung ges, iki aku seng buka, kuncine iseh na aku.

Karneng : owalah ok.

In the data (27) the switching in the sentence above when the utterance starts in Indonesian sentence into
Javanese sentence "aku nang gedung utama iki gess. Nunggu BRI buka.”

Lika : “mbak, na omah ta?” (28)

Mbak yani : "masih di sekolah. Habis ini pulang." (29)

Lika : oalah, iyo mbak

Mbak yani : engko dolen nak omahku yo. Mbek ngowo oleh-oleh dari kalimantan. Hohoho

May, $06^{\text {nd }} 2018$

Lika : "mbak, sido metu ta? Aku tak golek jamu sek ya??” (30)

Mbak yani : "ya jadi keluar." (31)

Lika : tak golek jamu sek, masku njalok jamu untune loro.

Mbak yani : iyo.. tapi ojok pacaran akro mbah doto engko ndang gak mole - mole.

Lika : mbah doto sopo? Engko mampir rumah sakit bp gapapa ta, ngeterno jamu tok?? Nek gak ngeterno jamu sek.

Mbak yani : iyo iso. Iki wes tak omongno mas didik.

Lika : okkeh, tak otw tuku jamu sekk.

In data (28) and (30) the switching in the sentence above when the utterance starts in Javanese sentence “mbak, na omah ta?", “mbak, sido metu ta? Aku tak golek jamu sek ya??", and then switches into Indonesian sentence in data (29) and (31) "masih di sekolah. Habis ini pulang." "ya jadi keluar."

Dialogue I , April $16^{\text {nd }} 2018$.

Lika : "iku cek dikerjakno dewe."

(32)

Pak Angky: "transport, samean iku

kan samean gawe dewe, disana

sekitar 100 - 180 ribu. Terus

transport bawa dari pelabuhan dari

kota besarnya Bulungan ke

tambang?" (33)

Karneng : kalau bapak iku kan bawa kayu.

Pak angky : iya, bawanya kayu gaharu

kalimantan, pertanyaan saya itu 
apakah dana bersihnya sampai 100

juta?

Karneng : gaharu itu kan pak

Pak Angky : iyo gaharu, telu meter.

Lika : "eh, jangan! rugi loh mereka

iku. Coba modal bibit gak usah

ngasih makan uang panen kalau

panennya 3 kali 100 juta." (34)

Pak Angky : iya itu sehari - harinya.

Lika : iya sehari - harinya itu pake,

kalau harian sehari bisa dapat 500

ribu.

Pak Angky : 2 hari?

Lika : per hari pak, eh enggak sih pak

2 hari sekali.

In the data (32) the switching in the sentence above when the utterance starts in Javanese sentence "iku cek dikerjakno dewe." And then switches in Indonesian sentence in data (33) and (34) “transport”, “eh, jangan!”

\section{Intra - Sentential Code Switching. Intra-sentential switching occurs within a clause or sentence boundary, where each clause or sentence is in one language or another. The Intra - Sentential Code Switching can be shown as follows at seen in data $16,17,18,19,20,21$ and 22:}

\section{[15]}

\section{Data 3}

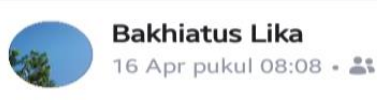

Yang tau tempat pembuatan amplang tolong bagi info ya ...

Rofiul Ummah dan 28 lainnya

$$
\text { ם Suka }
$$

The picture was taken by April, $26^{\text {nd }} 2018$ at

08:00

[16] Boled godongan : “up” aja deh ga tau aku." (33)

Lika : ndutttt.
Boled gedongan : hahaha

Lika : “tak tunggu. Okkeh. "Urgent" nah" (34)

Boled godongan : yo yo.

Lika : -emoticon ketawa-

[17] mariyanti : ngolehno aku ta.

Lika : tenang mbak, tapi lulusno ya.

Wkwkwkw.

Maryanti : wkwkwkw beres.

Lika : nak geli ketapang aku ditinggal yuk.

[18] Minie : sabanar lama mbak. Lika : alamat lengkapnya dimana?

[19] Fahraes : Smd banyak.

Lika : makasih loh ya.

Fahraes : -emoticon ketawa-

Lika : - emoticon ketawa-

In data (33) and (34) in the sentence above, the sentence starts in English "up" and followed by the Malinau phrase "aja deh ga tau aku." And the switch back to the base langauge "tak tunggu. Okkeh. "Urgent" nah" the meaning of code switching here is "up" is atas and "urgent" is penting.

[20] Lika : "coba "chat" aku, terus hapus." (35)

Baonk : aku dijalan pulang ika.

Lika : oalah.

Baonk : kamu ngapain.

Lika : nonton tipi nih.

Baonk : maksudnya apa nih.

Lika : “lihat aja di 'youtube', qorib minie swaya.” (36)

In the data (35) and (36) the sentence starts in Indonesia "coba “chat” aku, terus hapus.", "lihat aja di 'youtube', qorib minie swaya." And followed by the English phrase "chat" and "youtube". The meaning of code switching is "Chat is obrolan" and "Youtube is situs berbagi video."

[21] Eky : Bs.

Lika : iya ki, ee aku ditanjung.

Eky : apa kabar ne.

Lika : "baik, 'alhamdulilah', tumben ngechat. Ada apa ni." (37) 
Eky : gapapa bah, gimana kuliah mu. Lika : proses akhir li, doain ya, kamu gimana kabarnya?

Eky : Alhamdulillah baek, skripsi sudah.

Lika : lagi nyusun nih.

March, $01{ }^{\text {nd }} 2018$

Lika : tadi aku lihat pak ari di rumah sakit

Eky : oo sakit mungkin dia, aku masih di ktt ne.

Lika : ndak, rame - rame mereka. Jenguk kali. Mau negur malu aku, lama ndak ketemu.

Eky : hehe tegur aja bah.

Lika : malu lah, nanti beliaunya lupa pula.

In data (37) the sentence stars in Indonesia "baik, 'alhamdulilah', tumben ngechat. Ada apa ni." And followed by the Arabian phrase 'Alhamdulillah.' The meaning of code switching here is "bersyukur."

[22] Lika : nyo?

Ujie : iya nyo.

Lika : “jaringan “internet” $k u$

radak - radak." (38)

Ujie : kenapa bisa? Gangguan mungkin.

Lika : paketannya mulai ngadat.

Ujie : “aku sisa paketan

“chatingan" aja ni." (39)

Lika : "aku "videomax" aja nyo." (40)

In the data (38), (39) and (40) the sentence starts in Indonesian "jaringan "internet" $k u$ radak - radak." "aku sisa paketan "chatingan" aja ni." "aku "videomax" aja nyo." And followed by the English phrase "internet", "chatting" and "videomax." The meaning of code switching here is "internet is penyedia jaringan", "chatting is obrolan" and "videomax is paket film."

The Function Of Code switching Used By Malinau Students In Lamongan
1. Referential Function of Code Switching This function occurs when there is lack of knowledge of one language on certain subject by Gumperz and associates, Poplack, and, Scotton (in Apple and Muysken, 1987:118-120) that is four of the six functions of code swtiching. In addition, a specific word from one of the languages involved may be semantically more appropriate for a given concept. Here is the example of the code switching:

1) "up" aja deh ga tau aku." DATA 3 (32)

2) "tak tunggu. Okkeh. "Urgent" nah" Data 3 (33)

3) "coba "chat" aku, terus hapus." Data 3 (34)

4) 'lihat aja di 'youtube', qorib minie swaya." Data 3 (35)

5) "jaringan "internet" $k u$ radak radak." Data 3 (37)

The data above can be classified as referential function, because the occurance code switching in data above is that it is more appropriate and also suitable for the speaker to discuss the topic using the English word " $\boldsymbol{U p}$ ", "Urgent", "chat", "youtube", and "internet". In Indonesian, this word has to be explained with short explanation to gett some information in English word.

2. Directive Function of Code Switching

This directive function involves the hearer directly. It is includes a person more by using her or his language. Here is the example:

1) nah, ngak jadi aku kerumahmu hari ini, “mata ku kena cabai". DATA 1 (1)

2) "malas aku balik nah," tapi ya sudah lah. Iya nyo. DATA 1 (2)

3) "ndak kangen kah kalau ndak balik.” DATA 1 (3)

4) tidur sama ulenya dia hehehe "tahan juga dia tidur sama kau ti" haha. DATA 1 (6) 
5) hehe, ada mamaknya nah tadi habis youtube.an sama aku tuh "modelnya jadi kek gitu.” Udah pindah rumah kah nah? Nahhhhhhh? DATA 1 (7)

$$
\text { Malinau sentence "mata } \boldsymbol{k u}
$$

kena cabai", "malas aku balik nah", "ndak kangen kah kalau ndak balik", "tahan juga dia tidur sama kau ti" and "modelnya jadi kek gitu" it shows that the speakers. And his friends mixed to identify through the use of two language between Malinau and Indonesian sentences in the same discourse.

3. Expressive Function of Code Switching It shows that the speakers emphasize a mixed identify through the use of two languages in the same course. This function of code switching here is the example:

1) "hemmmm, langsung balik deh,, tapi kan enak ndek kene dek. Wohhh enek urusan toh." DATA 2 (26)

2) Udah pindah rumah kah nah? "Nahhhhhhh?" DATA 1 (7)

The use of code switching in the data above indicated a change in expressive sentence of the conversation and the main function is highlight the information that has been conveyed.

4. Metalinguistic Function of Code Switching

Metalinguistics function of code switching comes into play when it is used to comment directly on the languages involved. Here is the example :

\section{1) "yo menyedihkan kak". DATA $1(13)$}

2) "jare bahagia dek." "Wes kadong cinta karo lele ndelok lele ae bahagia”. DATA 2 (14)

3) "ngurangi resiko kalo jalan - jalan juga iya”. “Enak kan". DATA 1 (15)

The data above can be categorized as serving metalinguistics function, it means that the writer wants to comment directly the topic which is being discussed. The use of the word "menyedihkan", "bahagia", "cinta" and "enak" also expresses people's feeling.

\section{CONCLUSION}

Based on the data analysis, the researcher found three types of code switching. They are Tag Code Switching, Inter-Setential Code Switching and IntraSetential Code Switching.

In this data, it is also analysis of Malinau student speakers occurring from the sentences in Lamongan. From the data, it is found types by Poplack (1980) as citied in Romaine (1995:122-123) and the functions of code switching by Gumperz and associates, Poplack, and, Scotton (in Apple and Muysken, 1987:118-120) which are referential, directive, expressive and metalinguistics. From this finding, the researcher can conclude that Malinau Students used almost the types and functions of Code Switching in Indonesia, Javanese, English and Malinau sentences in Lamongan.

The main purpose of this study is to investigate the phenomenon of Code Switching used by Malinau students in Lamongan. After doing this research, the researcher found some conclusions as follows;

1. The types of code switching found are three types, that is, tag code switching, inter-setential code switching and intra - setential code switching. Malinau student can be changed in the language in Lamongan when they are talking to another person. In Code Switching there are several forms of redirects such as entering different word and dialect forms of languages such as (English) and (Javanese), as for basic languages (Bahasa Indonesia) and (Bahasa Malinau). Factor of code switching, based on changes on the topic and the current situation, the speakers and opponents of speech and changes from formal to informal situation. So, the 
researcher make sure that the Malinau students in Lamongan are correct in Code Switching when she is talking to another person.

2. The functions of code switching revealed are four. They are \{referential function of code switching, directive function of code switching, expressive function of code switching and metalinguistics function of code switching). From some of these descriptions it can be concluded that the types and the functions of the code switching have a role in the language changes that occurred between Malinau students and the friends said to be viewed from the existing assertion in Chapter IV.

\section{REFERENCES}

Apple, R. And Musyken, P. (1987). Language Contact and Bilingiualism. London: Edward Arnold (online) https://www.unidue.de/ELE/Language_Contact_Ove rview.pdf, accessed on March, $10^{\text {th }}$ 2018.

Creswell, John W. (2009). Research Design : Qualitative, Quantitative, and Mixed Methods Approaches. Newbury Park: Sage Publications. (online)

https://vivauniversity.files.wordpress .com/2014/02/creswell-2008-

research-design-qualitative-

quantitative-and-mixed-methodsapproaches.pdf, accesed on June, $23^{\text {nd }} 2018$.

Eltharini, T. (2015). An Analysis Of Code Mixing and Code Switching Used By Cinta Laura In A Kompas Tv Program. Skripsi tidak diterbitkan. Lamongan: UNISLA.

Fishman, J. A.( ed.), (1968). Readings in the Sociology of language. Netherlands: Mouton and Co.
Publishers

(online)

http://www.academypublication.com issues/past/tpls/vol02/08/05.pdf, accessed on May, $20^{\text {nd }} 2018$.

Haughen, E. (1969). The Norwegian Language In America: A Study In Billingual Behavior. Bloomington:Indiana University Press. (online) https://www.researchgate.net/publica tion/275582798_The complexities of_bilingualism_in_Puerto_Rico, accessed on June, $21^{\text {nd }} 2018$.

Halliday, Michael Alexander Kirkwood, Angus McIntosh \& Paul D. Strevens. (1964). The Linguistic Sciences and Language Teaching. London: Longmans Green and co ltd. (Online) https://halshs.archivesouvertes.fr/halshs-

00220455/document, accessed on May, $12^{\text {th }} 2018$.

Holmes, Janet. (1972). An Introduction to Sociolinguistics. London and Newyork : Longman.

http://www.malinau.go.id/page/sejarahmalinau/15, accessed on April, $29^{\text {nd }}$ 2018.

Kachru, B. B. (1978). "Code-Mixing as a Communicative Strategy in India" dalam James E. Alatis (ed). International Dimensions of Bilingual Education. Washington D.C.: Georgetown University Press. https://www.researchgate.net/publica tion/272752877_English_as_a_plura 1_language_The_significance_of_Ya muna_Kachru, accesed on June, $23^{\text {nd }}$ 2018 .

Poplack, S. (1980). Sometimes I'll start a sentence in English y termino en espan ol" Toward a typology of code-switching. Linguistics 18, 581616 (online) http://www.sociolinguistics.uottawa. 
ca/shanapoplack/pubs/articles/Poplac k1980Sometimes.pdf, accessed on May, $23^{\text {nd }} 2018$.

Rahmadhani, Arinasari. (2013). An Analysis Of Code Switching Used In The Novel Negeri 5 Menara By A.Fuadi. Skripsi diterbitkan. Tulungagung: STAIN.

Romaine, S. (1992). Bilingualism. Blackwell Publishers: Cambridge. (Online) http://journal.uinalauddin.ac.id/index.php/Eternal/arti cle/download/2365/2298, accesed on June, $16^{\text {th }} 2018$.

Romaine, S. (1995). Bilingualism. 2nd edn. Blackwell. Oxford (Online) http://faculty.ucmerced.edu/khakuta/ research/publications/(1995)\%20$\% 20$ BILINGUALISM $\% 20 \mathrm{~K} . \% 20 \mathrm{H}$ AKUTA.pdf, accesed on July, $14^{\text {th }}$ 2018.

Sugiyono. (2006). Metode Penelitian Kuantitatif, Kualitatif dan $R \quad \&$ D.Bandung:Alfabeta.

Sumarsono, (2012). Sosiolinguistik. Yogyakarta : Pustaka Belajar dan SABDA (Lembaga Studi Agama, Budaya dan Perdamaian).

Stockwell, P. (2002). Sociolinguistics: A Resource book for students. London:
Routledge.

(Online)

http://www.cxrlinguistics.com/Uploa dFile/201112194315914.pdf, accesed on May, $25^{\text {nd }} 2018$.

Trudgill, P. (1992). Introducing Language and Society. the University of California : Penguin English. (Online)

http://home.lu.lv/ pva/Sociolingvisti ka/1006648_82038_wardhaugh_r_an introduction_to_sociolinguistics.pd f, accesed on June, $28^{\text {nd }} 2018$.

Wardaugh, Ronald. (1986). An Introduction to Sociolinguistics. Oxford : Basil Blackwell. (Online) http://lx16.yolasite.com/resources/\% 5BRonald_Wardhaugh\%2C_Janet_ M._Fuller\%5D_An_Introductio(Boo kZZ.org).pdf, accesed on April $19^{\text {th }}$ 2018.

Wardhaugh, Ronald. (1997). Introduction to linguistics. Toronto: Mac-Graw Hill Book Company. (Online) http://1x16.yolasite.com/resources/\% 5BRonald_Wardhaugh\%2C Janet M._Fuller\%5D_An_Introductio(Boo kZZ.org).pdf, accessed on June, $24^{\text {nd }}$ 2018 